\title{
AN EVALUATION OF THE INDONESIAN MINISTRY OF RELIGIOUS AFFAIRS' POLICIES CONCERNING TERRORISM, RADICAL RELIGIOUS MOVEMENTS IN CURRICULUM CONTENT AND PEDAGOGY OF SECONDARY EDUCATION
}

\author{
Nurlena Rifai \\ Syarif Hidayatullah State Islamic University of Jakarta, Indonesia \\ E-mail: nurlena@uinjkt.ac.id
}

Received: $07^{\text {th }}$ November 2015; Revised: $05^{\text {th }}$ December 2015; Accepted: $23^{\text {th }}$ December 2015

\section{Abstract}

The purpose of this study is to evaluate the Indonesian government policies on curriculum and pedagogy that responds the global phenomenon of radical and violent forms of Islam. Specifically I investigate whether the Ministry of Religious Affairs has designed a curriculum content in Islamic Religious Studies for secondary education that discusses key concepts such as radicalism, jihadi-takfiri movements, religious violence, and intolerance towards other faiths. These issues are a central concern to Muslims in Indonesia. This research uses a qualitative approach and descriptive method. My research attempts to answer why the Ministry of Religious Affairs has not included curriculum content that deals with contemporary issues of violent Islamic movements. The data had been collected through observation, documentation and interviews a number of officials of the Ministry of Religious Affairs and Ministry of National Education, education experts and practitioners, and students. The result of my study will be a recommendation to the Ministry of Religious Affairs and Ministry of Culture and Primary and Secondary Education for developing curriculum content deals with the question of radicalism and religious violence in a direct and honest way.

Keywords: religiuos education; educational evaluation; terrorism; radicalism

\begin{abstract}
Abstrak
Penelitian ini bertujuan untuk mengevaluasi kebijakan pemerintah Indonesia pada kurikulum dan pedagogik yang merespon fenomena global dari radikalisme dan bentuk kekerasan dalam Islam. Khususnya, saya menyelidiki apakah Kementerian Agama telah merancang konten kurikulum pada mata pelajaran Agama Islam untuk sekolah menengah yang mendiskusikan konsep-konsep seperti radikalisme, gerakan jihadi-takfiri, kekerasan beragama, dan intoleransi terhadap keyakinan lain. Isu-isu tersebut merupakan perhatian utama bagi muslim di Indonesia. Metode penelitian ini menggunakan pendekatan deksriptif kualitatif. Penelitian saya berusaha menjawab mengapa Kementerian Agama tidak memasukkan konten kurikulum yang menyelesaikan isu-isu kontemporer tentang gerakan islam radikal. Data diambil melalui observasi, dokumentasi, dan wawancara sejumlah pejabat kementerian agama dan kementerian pendidikan, para ahli pendidikan, praktisi dan siswa. Hasil penelitian ini berupa rekomendasi kepada kementerian agama dan kementerian pendidikan dan kebudayaan pendidikan dasar dan menengah untuk mengembangkan konten kurikulum yang mengatasi pertanyaan tentang radikalisme dan kekerasan beragama dengan cara yang langsung dan jujur.
\end{abstract}

Kata kunci: pendidikan agama; evaluasi pendidikan; terorisme; radikalisme

How to Cite : Rifai, N (2015). An Evaluation of the Indonesian Ministry of Religious Affairs' Policies Concerning Terrorism, Radical Religious Movements in Curriculum Content and Pedagogy of Secondary Education. TARBIYA: Journal Of Education In Muslim Society, 2(2), 178-190. doi:10.15408/tjems.v2i2. 3181.

Permalink/DOI: http://dx.doi.org/10.15408/tjems.v2i2.3181 


\section{Introduction}

The recent rise of ISIL (Islamic State of Iraq and Levant) in the Middle East has brought the issue of religious radicalism to the forefront of the public consciousness in Indonesia. There has been a wide belief that the group has found widespread support among Indonesians (Zada, 2002; $\quad$ Tumudi\&Sihbudi, 2005; Singh\&Mulkhan, 2012; Fealy\&Bubalo, 2007). Many consider that the development of radical religious ideologies in Indonesia during the past decade as an affront to the nationalist vision of a united and diversified cultural Indonesia (Syam, 2009).

Whatever the true scale of radical ideologies being 'imported' into Indonesia, and how much of the perceived threat to the material well being of Indonesians are actually real and how much of these are imagined are not issues that we will deal in this paper. (The Jakarta Post, August, 2014). The main premise that we will deal with is Indonesia's position as the largest Muslim populated country in the world and that willynilly it has become grounds for the contestation of religious authority and ideology of various Muslim groups, notwithstanding those commonly described as radical religious groups such as ISIL, al-Qaeda and others (Tan, 2015). Furthermore, religious radicalism, as referring to violence done under the name of religion, is not something new in Indonesia (Siroj, 2016). The recent manifestations have been the vigilantism of groups such as the FPI (Front for the Defence of Islam) (Tempo, 2014) to the suicide bombings of the JW Mariott dan Ritz-Carlton hotel in the Mega Kuningan are of South Jakarta (July 17, 2009) (Wikipedia, 2015). A number of riots targeting minority Islamic sects such as the Shi' ites and Ahmadiyah in a number of religions in Indonesia that have led to the death, injury and internal displacements of these communities are also expressions of hardline interpretations of
Islamic law (Kontras, 2015). However, despite the fact that the phenomena of religious violence is one of the major issues facing Muslims in recent years, the government has chosen to focus on the legal and ideological aspects of the 'war on terror', by toughening laws to criminalize radicalist tendencies and acts and denouncing it as an exclusively external or alien threat to national unity (Njoto-Feillard, 2014). The Indonesian government has not yet acknowledged that the contestation of religious ideology also take place in the field of education as an internal issue of Indonesian Muslims. If as the government claim extreme and violent form of Islam is a misinterpretation of Islam itself, what has the government done to educate and not just warn the public that this is the case? (Njoto-Feillard, 2012). This question is particularly relevant in Indonesia's case, since the government through the Ministry of Education and Culture and the Ministry of Religious Affairs has taken upon itself to provide religious instruction in the form of Islamic Religious Studies (PAI) from the elementary to postsecondary level. Our paper attempts to evaluate the content of PAI education in the secondary level, whether it deals with the contemporary issue of religious radicalism in Indonesia and abroad and if so how.

Our research focuses on the curriculum content of PAI education in the secondary level from the KTSP Curriculum of 2006 to its revision in 2013 that are published by the Ministry of National Education and the Ministry of Religious Affairs. We also examine revisions made by ministerial direction in 2011 that included material that specifically dealt with the isue of religious exclusivism, radicalism, and terrorism with concrete examples in Indonesia and beyond. As we will discuss later, this material was no longer included in the 2013 Curriculum. Furthermore, the purpose of this study is to evaluate the Indonesian government 
policies on curriculum and pedagogy that responds the global phenomenon of radical and violent forms of Islam. We intend our research to contribute to the future revision of the current 2013 Curriculum within the preview of the larger question of what is the most effective and sensitive way of responding to radical religious ideologies in the contemporary Indonesian context.

We may identify radicalism with religion when members of a religious community marshal religious doctrines and principles to justify extreme action, especially through violence and coercion (Damayanti, 2003). Responding to the growth of extremist religious movements in Indonesia, the prominent Indonesian religious scholar, Said Aqil Siraj, wrote that religious radicalism is a generic term that can be used to refer to the various forms of violence justified by religious precepts, whether or not these lead to actual physical damage or just on the level of rhetoric (Siraj, 2011). This occurs when narrow religious education combines with certain social and political realities (Wilner\&Dubouloz, 2009). The causes of violence-in particular politically motivated violence-are society is never a simple thing to explain and cannot be reduced to pure ideology or belief. What is clear however that is in the case of radical religious movements, the issues of poverty, unemployment, political alienation and disenchantment combine with a substrate of religious doctrines, which gives a character of absolutism and uncompromising morality of their adherents.

According to Horace M. Kallen, (Kallen, 1937), the religious radicalism that results in social radicalism - a climate of inter-communal antagonism-has three main tendencies. The first is that radicalism is a response to an ongoing situation. This response is usually in the form of evaluation, rejection or opposition. The issues rejected are diverse: they can take the form of an assumption, idea, institution, or values that they consider as being responsible for the existence of the prevailing condition they reject. Second, radicalism does not end with rejection, but follows it up with efforts to inaugurate an alternative order. This shows that radical movements offer a program of action and a worldview to back up their oppositional stance. Third, adherents of radical movements often have deep convictions with respect to their beliefs and the truth of their actions. This certainty is combined with the conviction of the falsity of whatever condition or system they wish to replace.

According to Veldhuis (2009), there are two stages of radicalization: the first is an identity that arises from a concern regarding social conditions on a macro level, such as participation of society (or the lack thereof), foreign policy, and perceived problems in political, economic, and cultural development. The second is the result of social interaction on a micro level, influenced by the media, friends, leaders, and collegial or working environment that creates the disposition for assenting to extreme belief systems and provides the motivation for acting them out (Tinka\&Staun, 2009).

Among religious communities, radicalism centers on the following claims and characteristics (yusdani, 2013):

1. Claim to truth. The adherents believe that their holy books and doctrines teach the pure and only truth, and that other sects, let alone other religions, are therefore false.

2. Blind and loyal adherence to the leadership of the group.

3. The goal to set up an idealized State or way of governance. The adherents believe in establishing God's rule on 
earth by inaugurating a morally upright and theologically correct society.

4. Vigilantism, in that these groups may opt to exercise coercive power outside those already wielded by the State.

The process by which an individual moves from the one to the other is a complex process and cannot be reduced to the mere fact of having extreme beliefs in the first place, though they constitute an important aspect thereof (Jerome $P$, 2013). A critique or analysis of literalistic hermeneutics - one of the hallmarks of Islamic fundamentalism - would be useless in explaining the phenomena of terrorism, unless we also consider the social, economic and political condition of the individuals involved (Laqueur, 2002). In our study, we therefore hold to the premise that acts of terrorism are one of the many characteristics of radicalism.

\section{Method}

This research uses a qualitative approach and descriptive method. The data had been collected through interviews, observation, and documentation. The number of officials of the Ministry who oversees Religious Islamic Studies in the secondary level, ie. Ministry of Religious Affairs and Ministry of Education had been interviewed and also had been interviewed education experts and practitioners in the field, such as teachers and headmasters, many of whom have offered their own material that deals directly on these issues.

The research also conducted survey through focus group discussion interviews with students in two high schools, the State Public High School III South Tangerang and Triguna High School, located at the city of Ciputat, the province of Banten. The research have chosen these schools because their thorough implementation of the relatively new 2013
Curriculum. These interviews are meant to examine how teachers understand the concepts of religious radicalim and terrorism and whether (despite aforementioned changes in the curriculum) they discuss these issues in class. Finally we have conducted interviews with officials in charge of the PAI curriculum and academicians. The technical aspect of analysing these data is based on triangulation approach.

\section{Results and Discussion}

As we have seen above, the development of radical movements in Indonesia owes much of their persistence to education. That is to say, one of the most effective means to convince individuals to join their cause is not to force them into, but to systematically inculcate the values and aspirations of the group. As a result, efforts of deradicalization cannot simply rely on forcing people to renounce radical beliefs, rather these efforts must include education, or rather reeducation, as a central aspect of the overall strategy (Harjono, 2011). As a result, the government can play an important role in offering a public education and cultural policy that offer an alternative worldview that of radical movements.

Public institutions of learning have an important role in minimizing religious radicalism. Such institutes are places where pedagogy is not only embodied in the actual content of the curriculum, but also in the values represented by the learning environment and the interactions between fellow students, and teachers (Khalid, 2015). This is all the more relevant for the curriculum of Islamic religious education (PAI) at school that are supposed to provide moral guidance based on religious/spiritual values. According to a standard exposition, the aims and methods of Islamic Studies in public education-from hereon referred to as PAI-are: 1) to increase 
faith and God-consciousness, 2) respect other religions, 3) maintain the multicultural character of Indonesia, 4) commit oneself toward national unity. Religious education in this context is focused more on moral action, and not only mere rote understanding. This means that the values just mentioned ought to become something the students take as their own and which they practice on a daily basis (Muhamimin, 2012).

In this section of the paper we will examine the contents of three PAI curriculum materials for the Secondary level, the Curriculum of 2006 (Mulyasa, 2007), revisions introduced by the Minister of Religious Affairs in 2011, and the newly implemented National Curriculum 2013, where PAI materials are also revised. In doing so, we attempt to chart out efforts of the Indonesian government to educate students about religious radicalism.

The Curriculum of 2006 does not include material on religious radicalism. Instead it contains material dedicated to the values of tolerance, work ethic, the development of Islam in Indonesia, national unity and harmony. This was in many ways a continuation of the previous PAI curricula, in that the government chose to focus on the teaching of moral principles that, if properly understood by the student, would necessarily preclude the option of radicalism.

In 2009, the government of then president Susilo Bambang Yudhoyono introduced changes to the national curriculum under the auspices the Ministry of National Education. The Ministry of Religious Affairs was responsible for revision of material on religious studies, through the corresponding directorial branches of the Ministry, i.e. the directorates of Islamic, Catholic, Protestant, Hindu, Buddhist, and Confucious education respectively-these being the so-called official religions of the State. One major change to the previous curriculum was emphasis on the multicultural character of the Indonesian nation. However, unlike previous curricula, the values of tolerance and mutual respect should then be given a religious basis by each of the official state religions. This was thought to be in line with the self-perception-a very Yudhoyono-era idea-that Indonesia was a religious nation (Kompas, 2011). The parties involved in the revision of the PAI material were officials of the Ministry of Religious Affairs and Ministry of National Education, university academics, educators and principals. The results of the committee were reviewed by another committee that consisted of academics, members of the pesantren education system-traditionalist Islamic schools, and educators.

The concrete result of Yudhoyono's policies came in 2011, when the Minister of Religious Affairs at the time, Suryadharma Ali, issued a KMA (Ministry of Religious Affairs Directive) regarding the National Education Standard, dated July 12, 2011. In it he stipulated that the material standard of the PAI must include a discussion of 'praiseworthy' acts such as kinship, respecting deferences, mutual cooperation, the practice of syuro (democratic decision making practices), etc., the directive also includes analysis of the root causes of "blameworthy" acts such as doctrinal exclusivism, radicalism, and terrorism and how to avoid them (KMA, 2011). However, when in 2012, this guideline was considered for the 2013 Curriculum, the Committee for Curriculum Development in 2012, of which I was a member, decided by majority decision to not include this material in the new curriculum. One of the reasons that were given for this exclusion was that many members of the committee felt that to openly talk about such "blameworthy" acts as radicalism and terrorism to students would incite them to imitate or actually commit them. Teaching about these acts in class may be taken as actually teaching them. The majority of the members of 
the committee decided that on this account the issue was too controversial to be included in the new curriculum (Meeting with Curriculum Development Committee, 2011). The KMA guidelines that mandated the inclusion of sociological analysis of the root causes of religious exclusivism, radicalism and violence was replaced by a general discussion on the importance of tolerance, peace and principles of non-violent action from the Islamic perspective. As a result, these guidelines never saw the light of day.

Thus what ended up in the final draft of the PAI Curriculum 2013 was no different than what it was prior to the supplemental KMA guidelines Lubis\&Ismail, 2015). The section concerned did not explicitly the contemporary issues of religious radicalism. Instead, it discussed the concept of brotherhood (ukhuwwah) in Islam, both between Muslims, who are bound together by a common creed, and between Muslims and non-Muslims, who are bound together by the common status as God's creation (KMA on National Seducation Standard, 2011). As examples the curriculum cited the policy of the prophet Muhammad who brought together the emigrants of Mecca (al-muhājirūn) and the Helpers of Medina (al-anșār), the latter of which fled from persecution at their home city.

\section{Reception of the PAI Material by Teachers and Students}

In order to find out whether the new curriculum of 2013 is effective in inculcating the values of tolerance and multiculturalism, we conducted interviews and surveys of a number of high schools. We asked teachers regarding what they think are the indicators of a successful PAI education, and inquired regarding their knowledge of the concepts taught in the curriculum that deals with the issue of violence and tolerance in society and what method they used in teaching this material in class. We also interviewed government officials responsible for the curriculum to verify what the government has done to ensure that the material are taught properly to students and that teachers are taught properly how to teach it. Finally, we surveyed students to find out what they believe are the lessons and central concepts of the curriculum section on tolerance and multiculturalism. We do this in order to find out how far the students are able to understand the material in its ideal form in the curriculum and whether there are major discrepencies and if so why? By obtaining insight on the reception of the curriculum on the field allows us to make better suggestions for improvement.

According to the PAI teachers in Triguna High School, the main indicators for success in PAI subject are if students are able to perform the injunctions and leave the prohibitions of religion. Simply put, this is measured on whether they perform the five daily prayers. Furthermore, one teacher put things this way: "basically the teaching of Islamic Studies in the high school level, especially in Triguna High School, is to teach students how to perform the devotional ritual properly and consistently. They do not need a more complex education in this regard. It is enough that they perform the obligatory rites. The same idea was expressed by the PAI teacher in South Tangerang State High School III, who said that non-religious based schools do not need to present difficult material in religious studies. What's important is that they do the basics required by the religion. It seems that for PAI teachers, the main indicator of their success as teachers is whether they can guide them to regularly perform the devotional rituals of Islam (Survey, 2015).

With respect to the concept of tolerance as included in the 2013 Curriculum, PAI teachers of Triguna High School said that the material 
use meant to teach students to respect people of different faiths. They understand toleration as a form of "Living Peacefully with Others of Different Religions" ("Kerukunan antar Umat Beragama"). One teacher cites as an expression of tolerance that during PAI classes, Christian students have the "freedom" to choose to skip the period (Survey, 2015). As for State High School III, a teacher appointed by local church authorities is assigned to teach Christian students their own religious studies material. According to the PAI teacher, this shows that the school maintains a tolerant environment between students of different religious committments. Furthermore, he mentions that he is in friendly terms with his counterpart of the Christian community. From this we find that for many PAI teachers, tolerance is really shorthand for peaceful interreligious cohabitation. The more universal aspects of tolerance such as human rights, freedom of belief, and the moral dimensions of mutual respect and personal integrity are not explored, and perhaps not known.

We also found that the local government, represented in this case by the Educational Office, has never conducted training or workshops on the issue of religious radicalism and terrorism, whether for students or teachers. In comparison the Office has held anti-drug campaigns for students (Education District, 2015). Amin Haedari, Director of Islamic Religious Education, in the Ministry of Religious Affairs, mentioned one effort initiated by the Ministry to deal with the problem of radicalism: they invited representatives of local student religious societies (Rohis) for a national workshop that contained material on human rights, religious radicalism, nationalism, tolerance, and openness. He presented this event as an example of the Ministry's seriousness in preventing radicalism among the youth (Haedari, 2015).
Towards the question whether the contemporary problem of religious radicalism should be included in the PAI curriculum at the high school level, the teachers of Triguna and South Tangerang State High School III, expressed different points of views. Some are reluctant to recommend it because they are worried that if they talk about it, students will be curious and will want to do it. They also feel that if this material is included, there will emerge the impression that Islam is a violent religion, which for them is not the case. However, other teachers expressed that they are not oppossed to the idea, but only if the intention is to show the kinds of actions that must be avoided and to help students to reject recruitment attempts.

According to the teacher of the Christian religious studies in State High School III, teaching students specifically about religious radicalism is important. How can they understand theoretically the issue of intolerance if they do not understand an important and current manifestation of it? As a result, he says that it is important to include a discussion on current forms of religious radicalism in the curriculum.

Based on the survey conducted on students of the Triguna High School and South Tangerang State High School, we identified the following prevalent attitudes with respect to the material on tolerance and multiculturalism in the Curriculum (Survey, 2015). Like their teachers, the students understand tolerance as peacefully living together with adherents of different religious groups. Their example of this is typically to be good friends with minority groups, Christians for example. Students admitted that they are not well informed about terrorism and radicalism. They find about radical groups and their beliefs from the television, not from school. When asked the question whether the Bali bombings were justified or not, many students responded with the expression "I'm 
confused." Some say that on the one hand they do not condone the morally loose culture of that part of Bali, with its drugs and free sex. However, on the other they feel the need to affirm that the struggle against this is a worthy cause. Many students who initially declared themselves against suicide bombings and mass killings suddenly become less convinced when confronted by this "defence for the sake of Islam" argument. This shows a deep confusion in the pedagogy of the section on tolerance in the Curriculum, as students often are unable to identify which moral or ethical premises are primary and which are contingent to context.

\section{Evaluation of PAI Material on Religious Radicalism}

In the previous sections we have discussed the history of PAI curriculum material pertaining to the issues of religious radicalism and the values of tolerance and multiculturalism. We have also presented results of our interviews with educators and students to gauge the effectiveness of the 2013 PAI curriculum. We now present a critique of the PAI curricula based on the results of the interviews and analysis of the content of the PAI material on the aforementioned issues. Our discussion centers on two major areas of contention, whether it is appropriate to include material relating to religious radicalism in the PAI curriculum, and second whether the real problem lies in larger issue affecting not only PAI content but the rest of the national curriculum, namely the question of pedagogy and teacher's competency in delivering the material.

At its inception, the 2013 Curriculum was expected to contribute efforts at preventing radicalism among the youth. One major section presented the specific issue of "Tolerance as a Means for Unity" (Mustahdi\&Mustakim, 2014). In this section, the editors include a discussion on the concept of tolerance towards differences, whether these are religious, ethnic or cultural group. They wrote that these differences should be the cause for conflict or opposition, but should be understood as an asset that must be sustained through mutual tolerance. Forcing another person to believe in something they don't believe in is wrong, especially if it is done through physical coercion. Nevertheless, even though in outline the content of this section is adequate, it focused more on toleration between adherents of religions, and the phenomena of organized religious radicalism and how to deal with that within the religious community in question was not discussed.

As we have discussed above this material in the PAI section of the 2013 Curriculum was a revision of the 2011 KMA guidelines for future PAI material, which included material that specifically discussed the phenomena of religious radicalism in an attempt to educate students about why these acts are considered wrong. The committee responsible for this revision felt that to teach explicitly about radical and violent acts was liable to incite students to do it. From this we see how the material of the 2013 Curriculum, which was meant as a response to the phenomena of religious radicalism, conveys ethical norms and expectations in a very general way. The material is decontextualized from the everyday reality of the students who will easily find on the Internet and television instances of vigilantism and violence committed in the name of Islam. The idealized examples of 'praiseworthy' action also do not inform students about the subtleties of moral choice and the complex sociological conditions that lead to acts of violence. Further, the material does not concretely discuss how to identify extremist idologies and how to avoid it. Is this a regress from the KMA material of 2011, which mandated the inclusion of concrete examples of radical religious movements and identification of the main tenets of their beliefs? (Lubis, 2015). 
The position of the committee that decided against integrating the KMA guidelines is echoed by a number of other scholars and researchers in the field. According to Ahmad Shodiq(Shodiq, 2015),..., "directly discussing the issue of terrorism and religious radicalism is to "vulgar" become PAI curriculum material. According to him, there is nothing wrong with dealing with these phenomena head on, but for the purposes of secondary education, the discussion must be softened and focus on general principles. If there should be a discussion on religious radicalism and terrorism, it should be placed in general ethics and citizenship classes instead of religious studies."

The same opinion is echoed by Muhammad Zuhdi. Since the phenomena of religious radicalism and violence is caused not only by religious doctrine, but also by social, economic and political factors, there should be no need to include material directly dealing with these phenomena in religious education. To do/by doing so would already fall into a "bias" of classification, giving the impression that religion is solely responsible for the violence committed in its name. We have mentioned above the inclusion of a section in the 2013 Curriculum that discusses the issue of tolerance and multiculturalism. According to Zuhdi, this is should be regarded as a positive move on the part of the government, though it would mean nothing if the values taught are put into practice (Zuhdi, 2015). However, according to him, the issue of tolerance should be part of a larger category of character building, and therefore should also be present in all subject classes and not just religion (Zuhdi, 2015).

Among educators, curriculum designers and academics, there is the fear of a number of misunderstandings. The first is the misunderstanding on the part of the students: that if they are taught directly about concrete examples of religious radicalism and violence they may influence to actually commit such acts. The second is the misunderstanding that conflates religion with violent expressions of its teachings. The latter concern is a valid one, as it responds to the constant demands upon Muslims to apologize for acts of violence committed in the name of their religion. However, though this concern is understandable, we should also take into consideration three things: the first is that even though it is clear that religious radicalism and violence are also caused by factors external to the religion itself, such acts are justified through religious discourse and text. Secondly, those who fall victim to these acts are Muslims themselves, many of whom, including scholars and the public, are already publically talking about the legal dan moral validity of extremist doctrines and acts. If PAI material discussing these issues occurs within the framework of internal and participatory discourse among believers, then does this not do away with the charge of apologetism? Furthermore what is the vulgarity of talking about issues that the most prominent Indonesian (and non-Indonesian) religious scholars are already talking about in the public, through the internet, television, and radio?

On the other side of the spectrum is Anas Shofwan, a member of the Ministry of Religious Affairs' research team on Radicalism, who argues that the PAI material on tolerance must be supplied with concrete contemporary examples of religious radicalism. Teaching the characteristics and history of violence done in the name of religion does not automatically incite people to do it. If taught within a framework of the importance of multiculturalism, respecting other people's beliefs, and tolerance, then the issue of religious radicalism, which students already witness on the news and the internet, would be a good example to begin fruitful class discussions. However, this inclusion must be preceded by comprehensive 
training of the PAI teachers on every level of government.

Granted, however, much of Shodiq and Zuhdi's concern is based on their larger skepticism regarding the current pedagogical approaches in PAI teaching and the quality of teachers themselves. With respect to the PAI curriculum of 2006, which does not differ in substance from that of 2013 with respect to its content about the values of tolerance and multiculturalism, Muhaimin has identified the following pedagogical problems (Muhaimin, 2006).

1. The PAI is unable to turn cognitive content of religious knowledge into values and meaning that are embodied internally rather than just understood or memorized.

2. The PAI is not implemented in view of and in synchrony with other subjects taught at school.

3. The PAI fails to stay relevant in the face of social change. It ignores history and presents a static presentation of the religion and its teachings. As a result, the content of the PAI are often regarded as being separate from everyday life.

The various criticisms of the PAI curriculum focused on its methodology and orientation that were considered to be normative rather than critical, with an overemphasis on the cognitive and theoretical aspects of learning. As a result, the curriculum fails to respond in a relevant way to the social change currently taking place. It is as though the values taught in the curriculum exist in a static and separate universe of ideal behaviour and beliefs, without history and without change. This has led to the common misconcpetion among students that religious teachings are something separate from daily moral choices they have to make, and that they exist only in certain ritual contexts (Muhaimin, 2006). Furthermore, the method of teaching still relies on monological presentation, which can border on indoctrination. However, teaching on moral and spiritual values should emphasize more on dialogical approaches that includes participatory learning and role-playing, which involves the cognitive, affective and psycho-motoric development of students (Muhaimin, 2006). Furthermore, according to Anas Shofwan Khalid, teachers are not well equipped with an adequate theoretical understanding of such values as multiculturalism and tolerance. With respect to such a sensitive and current issue such as these, the quality and range of knowledge of those teaching the material is crucial for the message to get across (Zuhdi, 2015).

The existing material on tolerance and multiculturalism is also found lacking. According to Shodiq, the material only includes tolerance between religions and nothing about tolerance between different sects of Islam. Furthermore, the material is often taught only for one or two classes within the semester. As a result, both the teacher and the students' understanding of tolerance is limit to generalities and does not go to details such as the history of the various social movements that struggled for equality and freedom. If generalized education this is not followed by a teaching method and a school environment that values and practices toleration of other faiths, ethnic groups, and language, then the curriculum material would be useless. Given the varying quality of schools in Indonesia's many regions, some learning environment would be more conducive than others.

I agree with Zuhdi and Shodiq's concern that religious radicalism is not just a doctrinal issue and should therefore be dealt with on a larger framework and not just religious. I agree therefore that the same material should also be discussed in citizenship and general ethics classes. However, I think that there is space to 
talk about religious radicalism and violence as an internal issue of Muslims. After all, the victims of terrorist acts are overwhelmingly Muslims, their actors are Muslims and those speaking up in support and against them are also Muslims (BBC News, 2015). The fear of being perceived of conflating Islam with terrorism is the fear of being indicted by some external party. But this should not be an issue for Muslims if what is at stake are the well-being of Muslims themselves and the arguments used are those from an Islamic perspective and sources (www.the age, 2015).

\section{Conclusion}

When we compare the results of our interviews of teachers and students in Triguna High School and South Tangerang State High School III with the evalution of the PAI curriculum by the aforementioned academicians and observers, we find that their overall criticism of the PAI material, in particular regarding religious radicalism and violence is warranted. Teachers and students conceptualize tolerance in a very limited way. One teacher cites that fact that a Christian student does not have to participate in Islamic studies as an instance of such toleration. Friendliness or good social relations with others of religious faith is also cited as a prime example of toleration. Although these are important aspects of living in a multicultural society, the concept of toleration as a corrollary of freedom of expression and belief of an individual does not seem to be part of the conceptual understanding. Furthermore, the overwhelming emphasis has been on tolerating others of different faith or ethnic origin, where the fact of difference is already assumed. But what about differences that arises within a religious community, such as sectarian debates and conflicts? The curriculum as it stands now is not equipped to deal with this issue.
The lack of conceptual precision is also seen in how students admit that they are 'confused' when pressed about the issue of the Bali bombings. Most of their knowledge of thorny issues such as this derives from television and the internet. It is very unlikely that they would receive nuanced views from either of these mediums.

With respect to this problem of content, I recommend that the KMA guidelines, which stipulate that PAI material must include a discussion of modern forms of religious radicalism and violence, should be reconsidered for future PAI material. The content on the values of multiculturalism and tolerance should discuss the issue of violent acts perpetrated against members of the same religious community and between religious traditions. This should be done in an open and transparent way. Sensitive terms such as radicalism, exclusivism, violence, terrorism, tolerance, respect, should be defined and concretely described. The material should also contain reasons how and why acts of vigilantism and violence based on religious faith is wrong from an Islamic perspective. Many prominent religious scholars, such as Nurcholish Madjid, Abdurrahman Wahid (Gus Dur) and Quraish Shihab, have been writing on this issue for a long time, and so this hermeneutical framework is already in wide currency (Madjid, 2008). The idea however is not to engage in a refutation, but to also place the material within the larger framework of ethical conduct (akhlāq) and highlight the positive aspect of multiculturalism and openness to doctrinal and methodological differences within religious communities (Madjid, 2008; Madjid, 1999).

As for the issue of pedagogy, we recommend that in the teaching of the issues of tolerance and multiculturalism, teachers should be trained in delivering the material in a dialogical method. As Azra points out, when teaching the ethical 
dimensions of these topics, teachers should be trained to use a creative and participative pedagogy (Azra (2015). This is because ethics is not a matter of cognitive understanding but of action and habit.

\section{References}

Alhasany, M. 3 cara Merekrut Anggota, http://indonesiana.tempo.co/read/38282/2 015/03/17/ratu_kalingga/3-cara-merekrut-anggota\#.VTX_h46q4qE, akses 21 April 2015.

Azra, A. (2015). Tantangan PAI: Radikalisme, Peningkatan Efektifitas dan Peran PAI. Paper presented at General Studium Faculty of Education and Teachers Training, April 13, 2015.

BBC, Sekitar 20 pesantren ajarkan radikalisme, http://www.bbc.co.uk/indonesia/berita_in donesia/2014/08/140828_kemenag. akses 19 April 2015.

Berman, E. (2009). Radical, Religious, and Violent. The New Economics of Terorism. Cambridge, Massachusetts: Massachusetts Institute of Technology.

Bjelopera, J. P. (2013). American Jihadist Terrorism: Combating a Complex Threat. Washington, DC: Congressional Research Service.

Damayanti, N. P., Et al. (2003) Radikalisme Agama Sebagai Salah satu Bentuk Perilaku Menyimpang: Studi Kasus Front Pembela Islam. Jurnal Kriminologi Indonesia, 3(1).

Fealy, G. and Bubalo, A. (2007). Jejak Kafilah: Pengaruh Radikalisme Timur Tengah di Indonesia. Bandung: Mizan Pustaka.

Harjono, Y. Tangkal Terorisme dengan Pendidikan, http://nasional.kompas.com /read/2011/11/16/13205812/Tangkal.Ter orisme.dengan. Pendidikan, accessed 23 April 2015.

Kallen, H. M.(1937). Radicalism dalam Edwin R.A. Seligman, Encyclopedia of The Sosial
Sciences, XIII-XIV. New York: MacMillan Company.

Kamus Besar bahasa Indonesia, Radikalisme, http://kbbi.web.id/radikalisme

Kompas.com/read/2011/20/5, Lima Tujuan Gerakan Pendidikan Karakter (Five Aims of Character Education Movement).

Kontras. Kasus kekerasan terhadap Jamaah Ahmadiyah adalah kejahatan terhadap kemanusiaan: Komunitas Internasional harus turun tangan, http://www.kontras.org/index.php?hal=sia ran_pers\&id=1232, accessed 21 April 2015.

Laqueur, W. (2002). A History of Terrorism. New Jersey: Transaction Publishers.

Loubere, L. A. (1974). Radicalism in Medierranean France: Its Rise and Decline, 1848-1914. New York: State University of New York Press.

Madjid, N. (2008). Tradisi Islam: Peran dan Fungsinya dalam Pembangunan di Indonesia, second edition, Jakarta: Paramadina dan Dian Rakyat.

.(1999) Cita-cita Politik Islam Era Reformasi, edited by Wahyuni Nafis, acknolegment by Budhy MunawarRachman, Jakarta: Paramadina.

Minister of Religious Affairs' Decision on Guidance of National Standard Development of Islamic Religious Education at Schools, July 12, 2011

Mulyasa, E. (2007). Kurikulum Tingkat Satuan Pendidikan. Bandung:Remaja Rosdakarya.

Muhaimin, dkk. (2012). Paradigma Pendidikan Islam. Bandung: Rosda Karya.

Muhaimin. (2006). Nuansa Baru Pendidikan Islam. Jakarta: Raja Grafindo.

Mustahdi and Mustakim. Pendidikan Agama Islam dan Budi Pekerti, SMA/MA/SMK/MAK Kelas XI. Jakarta: Kementerian Pendidikan dan Kebudayaan. 2014. Bab 11NU Online, 12 Ormas Islam Keluarkan Pernyataan Bersama Tolak Radikalisme, 
http://www.nu.or.id/a,public-m,dinamics, detail-ids, 1-id,24106-lang,id-c,warta$\mathrm{t}, 12+$ Ormas+Islam+Keluarkan+Pernyataan +Bersama+Tolak+Radikalisme-.phpx, akses 24 April 2015.

Njoto-Feillard, "ISIL, a Growing Threat in Indonesia?,"; Fatah, A. (2012). Budaya Toleransi dalam Pembelajaran Pendidikan Agama Islam (Tolerance Culture in Learning Islamic Religious Studies). Tangerang Selatan: Penerbit YPM..

Njoto-Feillard, Gwenaël, "ISIL, a Growing Threat in Indonesia?," Asia Pacific Bulletin (No. 278: September 23, 2014).

Singh, B. and Mulkhan, A. M. (2012). Jejaring Radikalisme Islam di Indonesia. Yogyakarta: Bangkit Publisher.

Siraj, S. A. Pemerintah, Terorisme dan Radikalisme.

http://hankam.kompasiana.com/2011/04/ 17/pemerintah-terorisme-dan-radikalisme355537.html, accessed 20 April 2015.

Radikalisme Agama (Religious Radicalism), http://www.nu.or.id/a,public-m,dinamics,detail-ids,4-id,27794-lang,id-c,kolomt,Radikalisme+Agama-.phpx, accessed 19 April 2016.

Syam, N. (2009). Tantangan Multikulturalisme Indonesia: Dari Radikalisme Menuju Kebangsaan. Yogyakarta: Kanisius.

Tinka, V. and Staun, J. (2009) Islamist Radicalisation: A Root Cause Model. Den Haag: Netherlands Institute of International Relations Clingendael.
Tempo. Daftar Kekerasan FPI di Lima Provinsi, http://www.tempo.co/read/news/2014/11/ 13/078621646/Daftar-Kekerasan-FPI-diLima-Provinsi, Accsess 20 April 2015.

Wikipedia. Bom Jakarta 2009. http://id.wikipedia.org/wiki/Bom_Jakarta _2009, accessed 20 April 2015.

Wilner, A and Dubouloz (2009). Homegrown Terrorism and Transformative Learning: An Interdisciplinary Approach to Understanding Radicalization. Ottawa: Canadian Political Science Association Conference.

Yusdani. (2013). Menguak Akar Kekerasan Benuansa Agama. Buletin Al-Islamiyah. Yogyakarta: Universitas Islam Indonesia.

Zada, K. (2002). Islam Radikal :Pergulatan Ormas-ormas Islam Garis Keras di Indonesia. Jakarta: Teraju.

\section{Interviews and Survey}

Interview with Muhammad Zuhdi, Ciputat, Tuesday, March 10, 2015

Interview with Ahmad Shodiq, Ciputat, Friday, March 13, 2015

Interview with Anas Shofwan Khalid, Jakarta, Thursday March 12, 2015

Interview with Amin Haedari (Director Of Islamic education at School)

Interview with Halfian Lubis, Official of Ministry of Religious Affairs, Tuesday February 102015

Interview with Buchori Ismail (Puskur Kemendikbud), Jakarta, Tuesday, February 10, 2015

Interview with official of Education District, South Tangerang, Tuesday, February 10, 2015 